\title{
THE EFFECT OF PWHT ON WELD PROPERTIES OF TITANIUM ALLOY FOR REFURBISHMENT OF AIRCRAFT ENGINE EXHAUST CONE
}

\author{
Husaini Ardy, Sigit Yoewono \\ Bandung Institute of Technology \\ Department of Materials Engineering \\ Ganesa 10, Bandung 40132, Indonesia \\ tel.: +62 22 2512457,fax: +62222502265 \\ tel.: +62 22 2504243, fax: +62222534099 \\ e-mail:husaini@material.itb.ac.id,sigit@ftmd.itb.ac.id
}

\author{
Arif Sugianto \\ Garuda Maintenance Facilities(GMF) Aeroasia \\ Engineering Service Department \\ Soekarno-Hatta Airport, BUSH 19130, Indonesia \\ tel.: +62 215508021 , fax: +62 215501282 \\ e-mail:arifs@gmf-aeroasia.co.id
}

\begin{abstract}
The mounting bolt hole of aircraft engine exhaust cone was found cracked in the weld area. Exhaust cone material is $\alpha / \beta$ titanium (Ti-6Al-4V) alloy. The cracked section will be repaired by welding to restore its function. The purpose of this research is to evaluate the effect of post weld heat treatment (PWHT) on ductility, grain size, and shear strength of Ti-6Al-4V plates (0.063 in. thickness) welded by gas tungsten arc welding (GTAW) using commercial purity (CP) titanium wire electrode (AMS 4951H). The weld quality was evaluated by non-destructive and destructive tests, using the acceptance criteria of AWS D17.1 and AWS B2.1 as references. The effect of PWHT was examined by preparing two weld specimens: with and without PWHT at $620^{\circ} \mathrm{C}$. Non-destructive inspection by dye penetrant and $x$ ray radiography tests revealed that the weld in these two specimens is free from surface and internal defects. Weld specimen without PWHT is brittle and failed during fillet break test, whereas PWHT specimen is ductile and pass the same test. Metallography observation was conducted to measured grain size of base metal and heat affected zone (HAZ). The average grain size of PWHT specimen is $18.40 \mu \mathrm{m}$ on base metal and $36.80 \mu \mathrm{m}$ on HAZ, and for nonPWHT specimen is $26.85 \mu \mathrm{m}$ on base metal and $52.10 \mu \mathrm{m}$ on HAZ. Using Hall-Petch approach, the yield strength is calculated about $920 \mathrm{MPa}$ on the base metal of PWHT specimen, which result in the shear strength of about $531 \mathrm{MPa}$. Under static loading, the shear stress on the outer surface of exhaust cone due to exhaust gas is about 38 MPa, which is much lower than material shear strength.
\end{abstract}

Keywords: Engine exhaust cone, Ti-6Al-4V, GTAW, PWHT, microstructure, grain size, stress analysis

\section{Introduction}

Exhaust system in an aircraft engine produces high velocity combustion gas and reduces the turbulence effect. It consists of two sections, exhaust nozzle and exhaust cone [8]. Exhaust nozzle controls the density and velocity of the combustion gas. Exhaust cone is to produce laminar flow and stabilized the combustion gas, and preventing the drag [7].

One of the exhaust cones in an aircraft engine was cracked in the weld area of the mounting bolt hole as shown in Fig. 1. Exhaust cone material is titanium alloy Ti-6Al-4V. Refurbishment instead of replacement of the exhaust cone is the option to reduce the maintenance cost. Refurbishment will be performed by welding repair using gas tungsten arc welding (GTAW) to produce high quality welding and close control of heat input. 


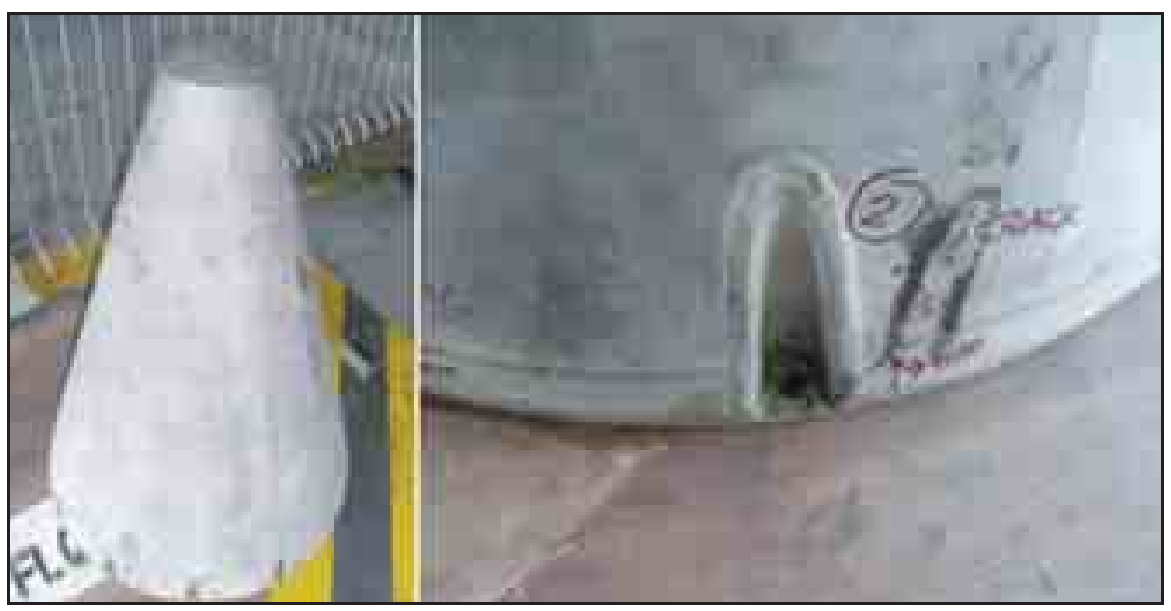

Fig. 1. Crack on the mounting bolt hole of the exhaust cone

Ti-6Al-4V alloy is an $\alpha+\beta$ alloy has been used extensively in the aircraft industry because of excellent weldability, good ductility, good formability, high strength, and lightweight [1]. The microstructure at room temperature consists about $90 \%$ equiaxed $\alpha$ enclosed by $\beta$ phase. Transformation of $\alpha$ to $\beta$ phase will occur at temperature above $883^{\circ} \mathrm{C}$ ( $\beta$ transition temperature). Mechanical properties of this material are very sensitive to the microstructure. Aluminium in the alloy is $\alpha$ stabilizer which raises $\beta$ transition temperature, whereas vanadium is a $\beta$ stabilizer, which lowers the transition temperature.

Welding of Ti-6Al-4V alloy would significantly change mechanical properties of material such as ductility and toughness due to heating cycle during welding. Low ductility of the Ti-6Al-4V weld is due to the increase number of $\beta$ phase volume fraction in the weld metal and heat affected zone. The formation of $\beta$ phase in weld metal can be suppressed using $\alpha$-titaniumfiller metal but it could not suppress $\beta$ phase formation in heat affected zone.

Ductility of the Ti-6Al-4V weld metal is also affected by residual stress. Restoration of ductility (stress relief) can be performed by the application of post weld heat treatment (PWHT). The right selection of PWHT parameters (temperature, time) can lower residual stress as high as $70 \%[4]$.

The objective of this research is to evaluate the effect of PWHT on the ductility, microstructure, and hardness of Ti-6Al-4V weld. Shear stress on the mounting bolt hole will be calculated using finite element method.

\section{Examination Procedures}

Ti-6Al-4V plate (1.60 mm thickness) was cut to the standard dimensions of welding procedure specification (WPS) specimen $(150 \times 100 \times 50 \mathrm{~mm})$ for T-joint [2]. Single pass welding was conducted using gas tungsten arc welding (GTAW) machine using commercially pure titanium welding wire (AMS 4951H), diameter of $1.59 \mathrm{~mm}$, and argon shielding gas (99.997\% purity) flow rate between 9 to $13 \mathrm{l} / \mathrm{min}$. Current, voltage, and travel speed were adjusted to produce heat input between 1.4 to $2.86 \mathrm{~kJ} / \mathrm{mm}$. The interpass temperature is between 100 to $120^{\circ} \mathrm{C}$. Two samples were prepared, with PWHT and without PWHT. PWHT was conducted at $620^{\circ} \mathrm{C}$ for one hour.

Surface defects on the weld metal was inspected by fluorescent liquid penetrant test, followed by radiography test to inspect weld internal defects, using the acceptance criteria of AWS D17.1 and AWS B2.1 as references. Hardness of base metal, heat affected zone, and weld metals were surveyed by micro Vickers hardness tester, load of 300 gr. Microstructures in base metal, heat affected zone, and weld metal were observed by optical microscope. Specimen cross section was ground, polish, and etched using Keller's reagent. Phases fraction and grain size were measured using image analyzer according to ASTM E1382 standard. 
Ductility of the weld metal was examined by fillet break test. The applied stress on the weld metal of mounting hole has been calculated by finite element method using Ansys and Autodesk Inventor 2011 softwares.

\section{Examination Results and Discussion}

T-joint of Ti-6Al-4V material has been weld successfully. One sample is PWHT and the other is not. Non destructive inspection by fluorescent penetrant test did not show any surface defects. The weld is also free from the internal defects. The edges from both sample sides were discard, and the remaining sample was cut into three pieces for metallographic test, hardness test, and fillet break test. Fig. 2 shows post cutting weld sample.

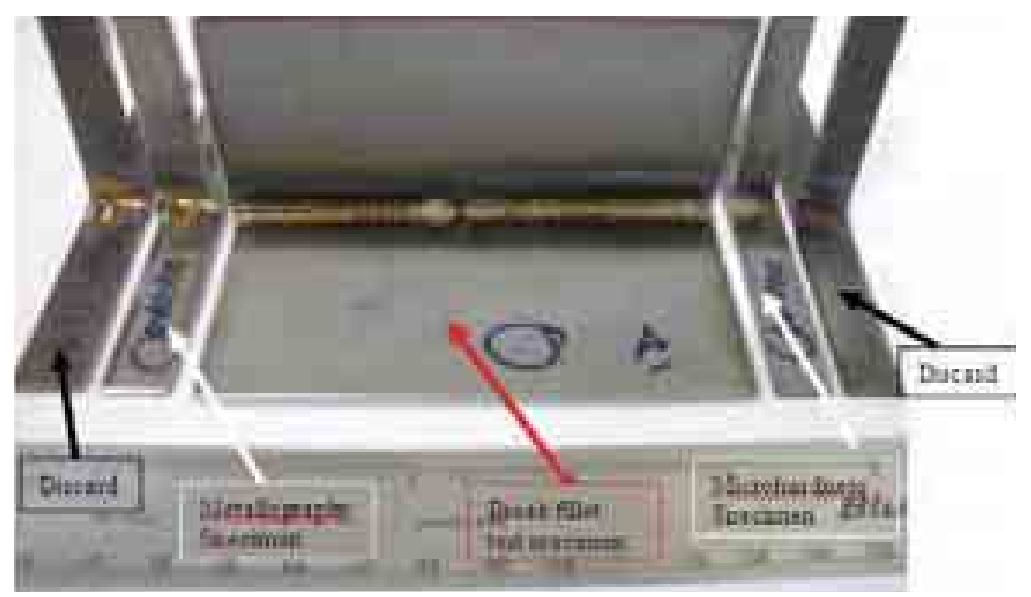

Fig. 2. Section of weld sample for destructive tests

Microstructure of base metal, heat affected zone, and weld metal of as weld sample are shown in Fig. 3. Microstructure of base metal consists of equiaxed $\alpha$ enclosed by $\beta$ phase. Heat affected zone have been exposed to high temperature and air cooled, the microstructure consists of $\alpha$ ' martensite as a result of $\beta \rightarrow \alpha$ ' transformation during cooling (supersaturated $\alpha$ ). Weld metal with $\alpha$-titanium filler metal has been exposed to high temperature above $\beta$ transformation temperature $\left(833^{\circ} \mathrm{C}\right)$. During cooling, $\beta$ phase transformed to Widmanstadten (acicular) alternate layer of $\alpha$ and $\beta$ phases [9].

Microstructure of base metal consists of $90 \% \alpha$ phase and $10 \% \beta$ phase [6]. Phase fractions in weld metal and heat affected zone have been measured by image analyzer, the result is shown in Tab. 1.

Tab. 1. Phase Fractions in Weld Metal (\%)

\begin{tabular}{|l|l|l|}
\hline \multicolumn{1}{|c|}{ Condition } & $\beta$ phase & $\alpha$ phase \\
\hline Non-PWHT & $13.82 \%$ & $86.18 \%$ \\
\hline PWHT & $11.95 \%$ & $88.05 \%$ \\
\hline
\end{tabular}

Post weld heat treatment process increases the amount of $\alpha$ phase in weld metal and almost close to the amount in base metal. Some of the unstable $\alpha^{\prime}$ in weld metal transforms to $\alpha$ during heating at $620^{\circ} \mathrm{C}$ and increase the fraction of $\alpha$ phase in weld metal. The increasing number of $\alpha$ phase in weld metal combined with the removal of residual stress will significantly increase weld ductility. This is confirmed by fillet break test results of PWHT and non-PWHT samples. PWHT sample passed the test, whereas non-PWHT sample was broken during the test. 


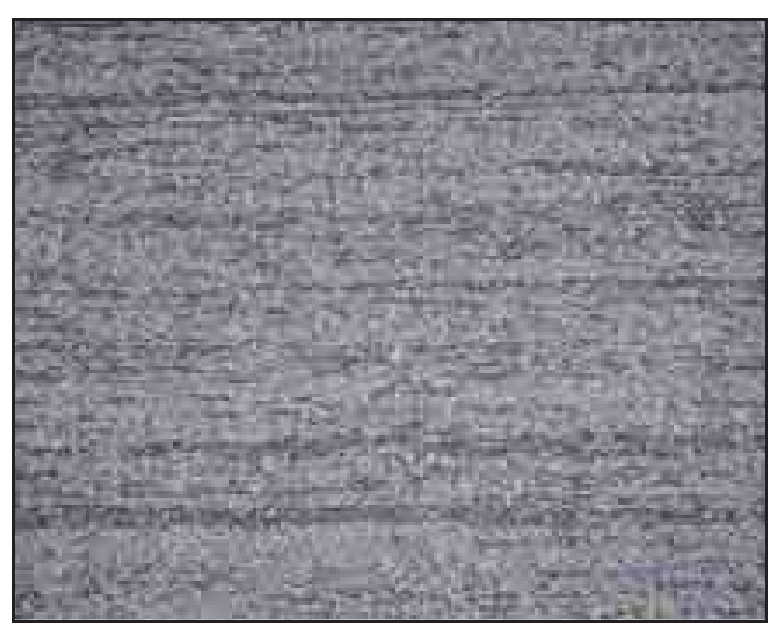

a. Base metal

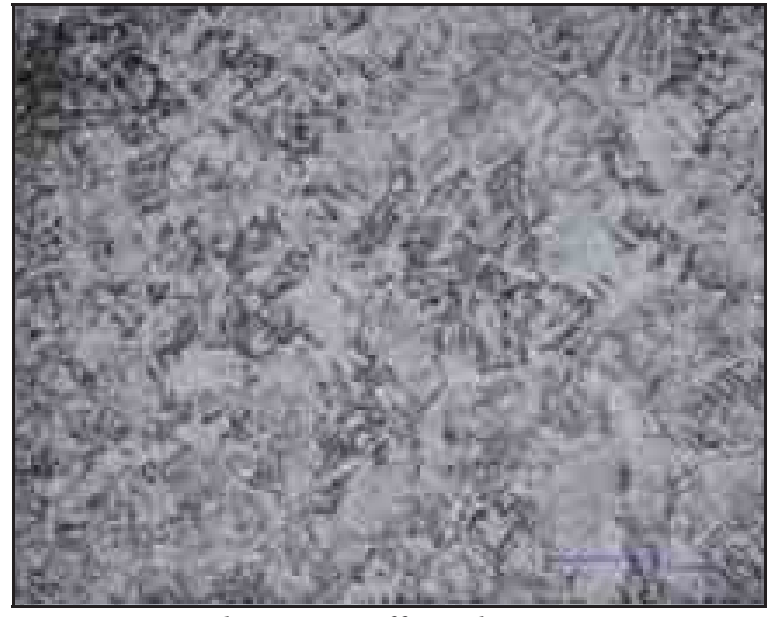

b. Heat affected zone

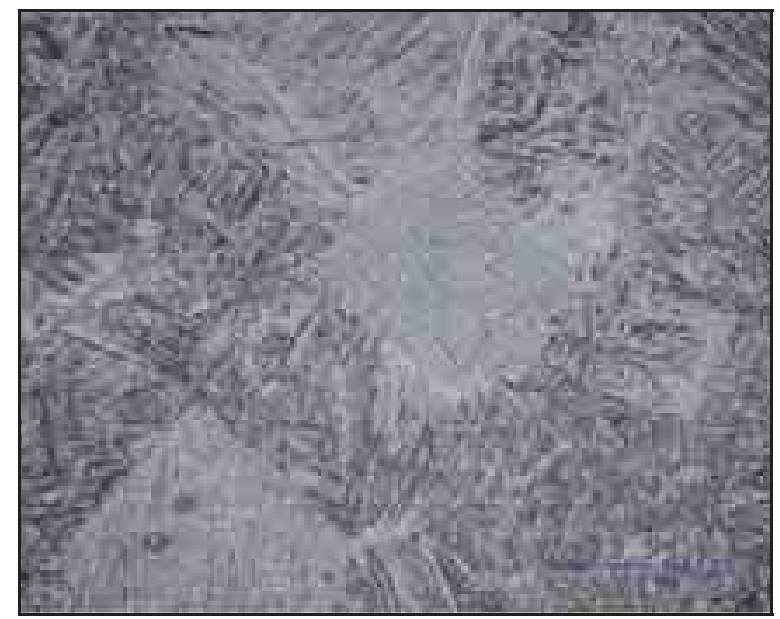

c. Weld metal

Fig. 3. Microstructure of as weld material

Hardness of base metal, heat affected zone, and weld metal have been surveyed by micro Vickers hardness tester at $300 \mathrm{~g}$ load. Summary of measurement is shown in Tab. 2. PWHT lowered the hardness of weld metal significantly due to the increase number of $\alpha$ phase and removal of residual stress. Hardness of HAZ increases after PWHT (Tab. 3) because of microstructure refinement and formation of supersaturated $\alpha$ phase $\left(\alpha^{\prime}\right)$. The change in base metal hardness around HAZ is not significant.

Tab. 2. Hardness (VHN) of Material

\begin{tabular}{|l|c|c|}
\hline & Non-PWHT & PWHT \\
\hline Base Metal & 306 & 316 \\
\hline HAZ & 315 & 337 \\
\hline Weld Metal & 233 & 220 \\
\hline
\end{tabular}

Tab. 3. Grain Size ( $\mu m)$ of Material

\begin{tabular}{|l|c|c|}
\hline & Non-PWHT & PWHT \\
\hline Base Metal & 26.85 & 18.40 \\
\hline HAZ & 52.10 & 36.80 \\
\hline
\end{tabular}


Yield strength of base metal and HAZ can be estimated using Hall-Petch equation [5]:

$$
\sigma_{y}=\sigma_{o}+k d^{-1 / 2}
$$

where $\sigma_{y}$ is the yield strength, $\sigma_{o}$ is the friction stress (= 878.65 MPa for Ti-6Al-4V material), $k$ is the strengthening coefficient $(=0.178$ for Ti-6Al-4V material) [10], and $d$ is the grain size. The yield strength of base metal and heat affected zone is shown in Tab. 4. The yield strength of base metal (920 MPa) is slightly lower than the literature value (930 MPa) [3].

Tab. 4. Yield Strength (MPa) of Base Metal and HAZ

\begin{tabular}{|l|c|c|}
\hline & Non-PWHT & PWHT \\
\hline Base Metal & 913 & 920 \\
\hline HAZ & 903 & 908 \\
\hline
\end{tabular}

Shear strength $(\tau)$ of base metal estimated using the equation (2) is about $531 \mathrm{MPa}$.

$$
\tau=0.577 \times \sigma_{y} \text {. }
$$

Shear force due to static friction between combustion gas and exhaust cone surface at room temperature will be calculated by finite element method using ANSYS software. Combustion gas velocity is $331 \mathrm{~m} / \mathrm{s}$. The simulation result is shown in Fig. 4a. The maximum shear force on the cone surface is $0.12 \mathrm{~N}$. Applied shear stress on the mounting weldment hole was calculated using Autodesk Inventor 2011 by dividing the shear force by exhaust cone cross section area. The applied shear force on the weld area is $38 \mathrm{~Pa}$ (Fig. 4b) which is much smaller than the shear stress of base material $(531 \mathrm{MPa})$. It is clear that the mounting bolt hole welding is very strong enough to cope with the combustion gas flow.

Further study to evaluate the effect of applied stress under dynamic loading and the estimate cyclic life of the weld joint is required as a basis for future repair.

\section{Conclusions}

Post weld heat treatment at $620^{\circ} \mathrm{C}$ for one hour has produced a sound Ti-6Al-4V weld. The weld ductility increases significantly due to the increasing number of $\alpha$ phase in weld metal combined with the removal of residual stress. The weld strength is high enough to carry the static load due to the combustion gas friction.

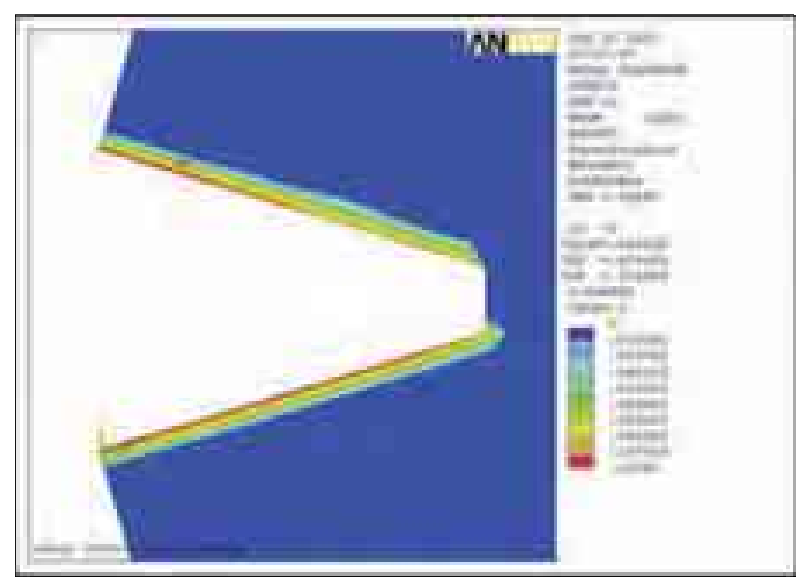

a. Shear force simulation result



b. Shear stress simulation result

Fig. 4. Stress simulation results 


\section{Acknowledgements}

The Authors are grateful to Garuda Maintenance Facilities (GMF) Aeroasia, Engineering Service Department for supporting this work. The Authors also wish their appreciation to Faculty of Mechanical and Aerospace Engineering-Bandung Institute of Technology-Indonesia for financial support to attend KONES2012 conference.

\section{References}

[1] American Welding Society (AWS), Welding Handbook Vol. 4: Metals and Their Weldability, $7^{\text {th }}$ ed. Miami, Florida 1982.

[2] American Welding Society (AWS), Vol. B2.1: Specification for Welding Procedure and Performance Qualification, Florida, USA 2005.

[3] ASM International. Metals Handbook Vol. 2: Properties of Non Ferrous Alloys, 4th printing, USA 1997.

[4] ASM International. Metals Handbook Vol. 6: Heat Treating, 4th printing, USA 1997.

[5] Dieter, G., Mechanical Metallurgy, $3^{\text {rd }}$ edition, McGraw-Hill, New York 1986.

[6] Domachie, M. J., Titanium: A Technical Guide, $2^{\text {nd }}$ ed., ASM International, USA 2000.

[7] Kumar, Bharat. An Illustrated Dictionary of Aviation. United States of America: McGraw Hill Company Inc. 2004.

[8] Lombardo, D., Advanced Aircraft Systems. USA: TAB Books.

[9] Porter, D. A., Easterling, K. E., Phase Transformation in Metals and Alloys, $2^{\text {nd }}$ ed., Van Nostrand Reinhold, New York 1992.

[10] Sirilar, P., Srichandr, P., Grain Refinement of $\alpha / \beta$ alloy, available at (retrieved on 26.07.2011): http://www2.mtec.or.th/th/seminar/msativ/pdf/M13.pdf. 